\title{
Chapter X. Analogy at War: Proportionality, Equality and the Law of Targeting
}

\author{
Gregor Noll*
}

Forthcoming in 43 Netherlands Yearbook of International Law (2013), pp. 205-230.

\begin{abstract}
This text is an inquiry into how the international community is understood in and through international law. My prism for this inquiry shall be the principle of proportionality in international humanitarian law, relating expected civilian losses to anticipated military advantage. To properly understand proportionality, I have to revert to the structure of analogical thinking in the thomistic tradition. Proportionality presupposes a third element to which civilian losses and military advantage can be related. In a first reading, I develop how this tradition of thought might explain the difficulties contemporary IHL doctrine has in understanding proportionality. If military commanders misconceive the third element as the sovereignty of their own state, they will invariably apply the proportionality principle in a paternalistic manner. This would obviate the most rudimentary idea of equality among states and do away with the common of an international community. In a second reading, I shall explore whether this third element could instead be thought of as a demos, while retaining the existing framework of analogical thinking. My argument is that this secularizing replacement is possible. Practically, its consequence would be a radical change in the task of the responsible military commander determining proportionality. That commander would now need to rethink civilians endangered by an attack as a demos whose potentiality must be preserved.
\end{abstract}

\section{Keywords}

Analogia entis, Analogy, Collateral Damage, Demos, International Community, International Humanitarian Law, Proportionality, Erich Przywara, Jacques Rancière, Targeting, War

\section{Contents}

X.1. Introduction

X.2. International Humanitarian Law and Proportionality in Targeting

X.3. The First Reading: On Proportionality 
X.4. The Second Reading: Demos and Polis

X.5 Negative Equality

\section{X.1. Introduction}

With this text, I want to inquire into the way the international community is imagined in and through international law.

I have chosen the principle of proportionality to work my way backwards into an idea of the common. The common is about that which is shared. Just as a comparison of two weights requires a scale, proportionality and equality presuppose something that enables comparison and equitable sharing. This is what we call the third, because it is indispensable for the two elements to be shared in a proportionate or equitable way (the Latin term of art being tertium comparationis). To bring out the idea of the common, I have chosen to resort to the extreme case of armed conflict. Jus in bello, or, international humanitarian law (IHL) presupposes the belief that a third element ensures the equal sharing of the common even across the divide that sets warring enemies apart. Therefore, I believe that IHL provides a suitable vantage point for inquiring into the way this third element is thought.

As a prism, I have chosen proportionality assessments in IHL, in which anticipated military advantage is related to anticipated civilian losses to determine the legality of an attack. Proportionality assessments allow me to ask how parties to an armed conflict are thought to be equal beyond all differences in resources, status or other. Since the third element is the only element parties have in common in the extremity of armed conflict, it is what ultimately guarantees the possibility of an international community.

Pieter Hendrik Kooijmans' The Doctrine of the Legal Equality of States provides me with a practical illustration on how an international community is always contingent on a third. Kooijmans 'intends to show the close relationship between the notions concerning the problem of equality in international law and the views that are held with regard to the foundations of this international law'. ${ }^{1}$ What, then, is the third

\footnotetext{
* Professor of International Law, Torsten and Ragnar Söderberg Foundations Chair in Commemoration of Samuel Pufendorf, Faculty of Law, Lund University, $<$ Gregor.Noll@jur.lu.se $>$. I owe thanks to the Yearbook's anonymous internal and external reviewers and to participants at the Proportionality Seminar at the Faculty of Law, Lund University, on 20 August 2012 for helpful comments and critique on earlier versions of this text. I am particularly indebted to B. S. Chimni, Ulf Linderfalk and Daniel
} 
element on which his version of equality pivots? An adherent to 'modern natural law', Kooijmans casts the third as God. 'The idea of a community', he writes, 'is inherent in the fact that Man was created after God's Image and of one blood', a 'fact' that he submits to be 'decisive for all inter-human relationships'. ${ }^{2}$ With this, he re-establishes tropes of thought that have followed Western thinking since it became indebted to Christianity: a categorical difference between the Creator and man as his creature, a categorical equality between one human being and another human being in their relatedness to that superior Creator, and the staging of any relationship within this tripartite structure of gradual divine revelation in world and time. This point of departure brings Kooijmans to prefer material 'equality in international law' based on valuation of concrete situations over formalist ideas of 'equality of states'. 'The idea of the law', he writes elsewhere, 'is a manifestation, with respect to the life of law, of the insight into the divine principles of order for this temporal reality and their relevance for a particular phase of culture'. ${ }^{3}$ In that, Kooijmans' God reveals Himself in the practice of a law worthy of its name. Closing Kooijmans' 1964 monograph, I remain struck by the perseverance, over time, of the Christian form of thought in international law. While his text does not aspire to theological sophistication, his narrative of equality comes across as so much more robustly structured than that of many contemporary international constitutionalists who offer faux-secular versions of these structures.

What to make of this? Is it at all possible to think of international law outside the structures that a long-dominant Christian theology has inherited to us ${ }^{4}$ What path then to choose, if I, unlike Kooijmans, do not think it adequate to embrace these structures with personal faith?

In earlier research, I have suggested that proportionality reasoning is part of a chain of equivalence legitimizing military necessity and creating the space for a

Steuer. Moreover, I have greatly profited from Luca Bonadiman's research assistance on philosophy, theology and Greek etymology. Thanks are also due to Marie Jacobsson for generous advice on the execution of the Lund project on IHL, Targeting and Military Training, of which this text forms part, and to the Torsten and Ragnar Söderberg Foundations for funding it.

${ }^{1}$ Pieter Hendrik Kooijmans, The Doctrine of the Legal Equality of States, Leiden (1964), p. 238.

${ }^{2}$ Kooijmans, supra, p. 196.

${ }^{3}$ Kooijmans, supra, p. 213.

${ }^{4}$ What enables me to ask this question is the work of contemporary international lawyers seeking to understand their discipline through its lingering theological roots or residuals. I felt Anne Orford's 'Trade, Human Rights and the Economy of Sacrifice', 18 Leiden Journal of International Law, pp. 179213 (2005), and Jennifer Beard's The Political Economy of Desire, Oxon (2007), to be particularly compelling in this growing body of literature. 
sacrificial logic. ${ }^{5}$ In the current contribution I want to consider whether it is possible to think beyond a sacrificial logic.

To this end, I shall develop two different readings of the third element enabling an international community. In the first of these two, I shall introduce a form of thinking proportionality that I see underpinning international humanitarian law. This form invites us to think of proportionality as a particular mode of an analogy. To explain how this form of thought emerged, I draw on philosophical and theological literatures, and in particular on the work of Erich Przywara. The second reading is my attempt to think proportionality through the idea of the demos. In that, I will emphasize the role of aesthetics in analogical thinking. A text by Jacques Rancière proved to be helpful in doing that.

With the first reading, I work myself backwards into earlier articulations of a form of thought that predetermines our possibilities of thinking equality and proportionality today. While IHL scholarship is cloaked in a secular language, it invariably affirms and reproduces a Christian form of thought in international law. With the second reading, I want to probe whether a secularized way of thinking equality and proportionality is conceivable. While the first reading explains how the analogical form of thinking the common assumes a Christian God, the second seeks to move the demos to the level of the third while remaining within the analogical form. My argument is that this replacement is possible. Its consequence would be a radical change in the task of the responsible military commander determining proportionality. That commander would now need to rethink civilians endangered by an attack in relation to a demos whose potentiality must be preserved.

\section{X.2 International Humanitarian Law and Proportionality in Targeting}

In this article, I shall focus on what has been described as a 'fundamental' text of the laws of war: a norm prohibiting an attack that is expected to cause incidental civilian loss excessive to its anticipated military advantage. This norm is often referred to as the 'principle of proportionality', although its textual rendering pivots on a relationship of excess rather than proportion. Jean-Marie Henckaerts and Louise

\footnotetext{
${ }^{5}$ Gregor Noll, 'Sacrificial Violence and Targeting in International Humanitarian Law', in Ola Engdahl and Pål Wrange (eds.) Law at War: The Law as It Was and the Law as It Should Be. Liber Amicorum Ove Bring, Leiden (2008), pp. 101-112. To apply Walter Benjamin's terminology developed in his Critique of Violence, my 2008 text is an effort to link proportionality to mythical violence, while the present text asks whether a particular form of proportionality assessment focused on the demos might end up in a contemplation of what Benjamin terms 'divine violence'.
} 
Doswald-Beck's study on Customary International Humanitarian Law, conducted under the auspices of the ICRC, found that the following formulation captured its content in general international law:

Launching an attack which may be expected to cause incidental loss of civilian life, injury to civilians, damage to civilian objects, or a combination thereof, which would be excessive in relation to the concrete and direct military advantage anticipated, is prohibited. $^{6}$

According to the study, this norm would be applicable in international as well as non-international armed conflicts. As international armed conflicts have dominated in the development of IHL, my discussion will mostly focus on this type of conflict to achieve the greatest possible clarity.

We know from another norm of IHL that attacks 'may only be directed against combatants' and that they 'must not be directed against civilians'. ${ }^{7}$ This norm is usually referred to as the principle of distinction. It provides the two major categories through which warfare is understood, determining that one is targetable and the other is not. The principle of proportionality, though, would seem to relate the military to the civilian in a more fine-grained way. It suggests the permissibility of unintended civilian loss, but only to a degree. Some form of interplay between the military and civilian is implied in it: where distinction severs, proportionality joins. If distinction provides the parts, proportionality makes them into a whole. So proportionality is inter partes as much as erga omnes.

The spatial and temporal reach of armed conflict has been growing together with the spatial and temporal reach of the parties to it. The military and the civilian appear as being ever more closely intertwined in that growth. With that, the principle

\footnotetext{
${ }^{6}$ Jean-Marie Henckaerts and Louise Doswald-Beck, Customary International Humanitarian Law, Cambridge (2005) (hereinafter CIHL), Rule 14, p. 46. This particular expression of the norm as customary law is preceded by a treaty law formulation in article 51.5.b of the Protocol Additional to the Geneva Conventions of 12 August 1949, and relating to the Protection of Victims of International Armed Conflicts, 8 June 1977 (hereinafter API), which proscribes as indiscriminate an 'attack which may be expected to cause incidental loss of civilian life, injury to civilians, damage to civilian objects, or a combination thereof, which would be excessive in relation to the concrete and direct military advantage anticipated'. The obligation to take precautions in article 57.2.a.iii API also reflects that norm. The qualification of the proportionality principle as 'fundamental' is Schmitt's. Michael N. Schmitt, 'The Law of Targeting', in Elizabeth Wilmshurst and Susan Breau (eds.), Perspectives on the ICRC Study on Customary International Humanitarian Law, Cambridge (2007), pp. 131-168, at p. 156. The Manual on International Law Applicable to Air and Missile Warfare offers another textual rendition of the proportionality principle: 'An attack that may be expected to cause collateral damage which would be excessive in relation to the concrete and direct military advantage anticipated is prohibited.' Program on Humanitarian Policy and Conflict Research at Harvard University Manual on International Law Applicable to Air and Missile Warfare, (2009), p. 10 (hereinafter HPCR Manual).

${ }^{7}$ Rule 1 CIHL. The formulations in treaty law provisions (arts. 48 and $51.2 \mathrm{API}$ ) are slightly different.
} 
of proportionality provides a major, or indeed, the major demarcation between lawful and unlawful conduct of warfare.

Or does it? Many participants in the discourse on applied IHL stress the importance of the norm only to openly avow the impossibility to explain its precise content. I will provide five examples from recent works on issues of targeting. ${ }^{8}$ First is a comment by Michael N. Schmitt, Professor of International Law and Chairman of the International Law Department at the United States Naval War College. Schmitt is one of the most prolific writers on IHL issues and enjoys a dominant position in contemporary discourse. Addressing the law of targeting as cast in the Rules of the CIHL Study, he remarks on the way the proportionality principle is expressed in Rule 14 CIHL (which I quoted at the beginning of this section).

In the first sentence of the section commenting Rule 14, he describes it as 'the rule which warfighters find most difficulty to apply in practice, because it involves the consideration of dissimilar values in relation to each other through application of a highly subjective standard, excessiveness'. ${ }^{9}$ The incommensurability argument is certainly not Schmitt's alone; it can be traced back to the positions taken by Poland and Syria during the negotiations resulting in Additional Protocol $1 .{ }^{10}$ The absence of a common measure for the two values might be a defect weighty enough to make any further comment on the proper application of the rule superfluous. Neither Schmitt nor other application-oriented international humanitarian lawyers seem to see it that way, though. After the quoted passage, he continues with elaborate comments (on

\footnotetext{
${ }^{8}$ The purpose of my five examples is to illustrate dominating patterns within the IHL literature. The majority of IHL authors affirms the existence and usefulness of the principle while being unable to detail its content. Occasionally, single writers voice scepticism on the content of the principle. A recent and questionable example is Samuel Estreicher, 'Privileging Asymmetric Warfare (Part II)? The "Proportionality" Principle under International Humanitarian Law', Chicago Journal of International Law (2012), pp. 143-157, claiming that this principle merely proscribes the excessive use of military force and does not require complex balancing. According to Estreicher, the standard of nonexcessiveness requires that the military use no more force than necessary to accomplish concrete, direct military objectives. "No complex, metaphysical "exchange value," no "comparison between things that [are] not comparable" is required', Estreicher concludes (p. 156-157, footnote omitted). To my understanding, his formulation of the standard justifies any amount of force and any number of civilian losses if only its necessity in achieving a concrete, direct military objective can be rationally argued.

${ }^{9}$ Schmitt, supra note 6, p. 156. Interestingly, the Commentary on the HPCR Manual suggests that '[t]he standard is objective in that expectations must be reasonable.' I am not sure that this is much of a contradiction: the Commentary's concept of an 'objective standard' is apparently a rather thin one. If anything, it illustrates that the use of terms as 'subjective' and 'objective' do not rely on a common understanding across the IHL literature. Program on Humanitarian Policy and Conflict Research at Harvard University, Commentary on the HPCR Manual on International Law Applicable to Air and Missile Warfare, (2010), p. 91, para. 6 (hereinafter HPCR Commentary).

${ }^{10}$ See the positions taken by Poland and Syria at the Diplomatic Conference, in CIHL Database, Practice on Rule 14, available at http://www.icrc.org/customary-ihl/eng/docs/v2_rul_rule14 (accessed on 20 September 2012).
} 
questions such as whether force protection may be counted in under the category of military advantage or whether reverberating effects must be counted in among civilian damages and losses). The 'consideration of dissimilar values' and the use of a 'highly subjective standard' under the proportionality principle obviously does not seem altogether futile to him. Had it been, he would hardly have spent his and our time on further details of its application. This move first expresses agnosticism on the functioning of the norm to then perform continued allegiance to it.

The pattern I see in Schmitt's text seems to permeate the targeting literature in IHL at large. ${ }^{11}$ My second example is Yoram Dinstein's standard textbook on the conduct of hostilities. ${ }^{12}$ Dinstein first states that "proportionality is the true guarantee of robust civilian protection from the effects of attacks in wartime" main difficulties"14 in applying the principle of proportionality and to conclude with a number of examples of excessive and non-excessive attacks. Yet I simply do not understand the principle governing why some of these examples are within and others outside the confinements of proportionality.

Joseph Holland is another writer who performs the move from agnosticism to allegiance, providing me with my third example. At the time when the article I quote below was published, he was posted as a Legal Officer with the Office of the Legal Advisor, Supreme Headquarters Allied Powers Europe (SHAPE), Casteau, Belgium. Holland first explicitly denies that proportionality assessments are useless. Here is his argument:

How, then, is this difficult, highly charged concept [of proportionality] to be applied? Is it so inherently flawed that is [sic!] cannot usefully be employed? Not at all. Obviously and despite the mathematical terms used earlier, there is no mathematical formula to balance expected incidental civilian losses and anticipated military advantage. Even less will there be a 'proportionometer' to assist commanders and others tasked with these difficult decisions. The military member (and it will be military personnel along with the occasional politician who inserts him or herself in the targeting process) will have to make a good faith, honest and competent decision as a 'reasonable military commander'. As has been pointed out, such judgments by experienced combat commanders are not likely to be the same as those made by

\footnotetext{
${ }^{11}$ The most recent monograph of relevance to this issue is William H. Boothby, The Law of Targeting, Oxford (2012). The analysis of proportionality runs over four of the book's 603 pages and basically reiterates the problems of incommensurability and subjectivity. I cannot see, however, that Boothby's text expresses a more fundamental doubt on the operability of article 51.5.b API.

${ }^{12}$ Yoram Dinstein, The Conduct of Hostilities under the Law of International Armed Conflict, Cambridge, $2^{\text {nd }}$ ed., (2010), pp. 128-138.

${ }^{13}$ Supra, p. 130.

${ }^{14}$ Ibid.
} 
human rights lawyers. Nor should they be. The combat commander has a wide range of responsibilities including, but not limited to, the successful execution of his mission and adherence to the law of armed conflict. So subjective are proportionality decisions that different reasonable experienced combat commanders are likely to differ on occasion. This subjectivity is widely recognised. ${ }^{15}$

In his rendering, the usefulness of proportionality assessments lies in the power it vests in the profession of the reasonable and faithful military commander. The main function of the principle of proportionality seems to be the way in which it conditions the thinking of the military commander, frisking out improper motives.

My fourth example of a move from agnosticism to allegiance is Ian Henderson's 2009 monograph on The Contemporary Law of Targeting, based on his doctoral dissertation. ${ }^{16}$ Henderson was a senior legal officer and Wing Commander with the Royal Australian Air Force in the 2003 coalition operations against Iraq, as the foreword written by his military superior intimates. Chapter 8 of his book bears the heading 'Proportionality'. After an introductory section, Henderson first devotes one section to the scope of military advantage and another to the scope of collateral damage. Section 8.4 then deals with the question 'What is meant by excessive?', and it is written with the military decision-taker as an imagined reader. Already in the second paragraph of this section, Henderson gives expression to his agnosticism, inter alia by stating that: '[u]nfortunately, and perhaps unavoidably, article 57 API provides no guidance on what is proportional (ie, not excessive) in this balancing test. ${ }^{17}$ But why is this absence of guidance 'unavoidable'? Surely, the proportionality norm in articles 51 and 57 are, as the travaux show ${ }^{18}$, an agreement to disagree. Yet I see no quarrels about the correct interpretation of the norm. This suggests that the 'unavoidable' mystery of its precise procedural demands must have other reasons.

Reproducing a standard pattern from the IHL literature on targeting, Henderson asks how many civilian deaths would be excessive in attacking a munitions factory. I can almost see him throwing up his hands at this question. From

\footnotetext{
${ }^{15}$ Joseph Holland, 'Military Objective and Collateral Damage: Their Relationship and Dynamics', Yearbook of International Humanitarian Law, pp. 35-78 (2004), at pp. 48-49. Footnotes omitted.

${ }^{16}$ Ian Henderson, The Contemporary Law of Targeting. Military Objectives, Proportionality and Precautions in Attack under Additional Protocol I, Leiden (2009).

${ }^{17}$ Henderson, supra note 16, p. 221. In a section on "Further research", Henderson writes that "the fundamental issue remains that it is difficult to determine exactly what is excessive in any given case", suggesting a comparative study of similar issues across legal regimes (p. 247).

${ }^{18}$ See supra note 10. During the negotiations leading up to the adoption of API, the Soviet Union and other Warsaw Pact Members were negatively disposed toward the proportionality principle, while the West was supportive.
} 
there on, he assumes the role of an advisor to a commander tasked to apply article 57.2.a.iii API; he points out that the judgment on expected civilian casualties and military advantage is that of a 'reasonable person', reminds that the value given to a human life may vary contextually and that unalike values of loss and advantage are compared and underscores that extensive collateral damage is not necessarily tantamount to excessive collateral damage. In doing that, he seems to suggest that our limited understanding of the provision in no way hinders our duty to perform its application in some way.

My fifth, and final, example is the 2010 Commentary on the HPCR Manual on the International Law Applicable to Air and Missile Warfare, which is the most recent attempt to restate the law in that field, drafted by a group of predominantly Western experts. ${ }^{19}$ The forward-looking character of assessing harm to civilians in relation to military advantage is once more underscored and views are offered on what is in- and excluded under each of the two categories of civilian loss and military advantage. Beyond that, the Commentary stands out in that it provides a negative as well as a positive determination of excessiveness:

The term 'excessive' is often misinterpreted. It is not a matter of counting civilian casualties and comparing them to the number of enemy combatants that have been put out of action. It applies when there is a significant imbalance between the military advantage anticipated, on the one hand, and the expected collateral damage to civilians and civilian objects, on the other. ${ }^{20}$

The authors of the quoted text recast the term 'excessive' as a 'significant imbalance'. While this adds no further precision, it leaves me with the expedient question what exactly this imbalance has to signify in order to render an attack unlawful.

But why this terse disqualification of concrete body counts? If the problem of proportionality would be resolvable by counting bodies and operating algorithms, ${ }^{21}$ no

\footnotetext{
${ }^{19}$ The HPCR Manual as well as the HPCR Commentary were elaborated by a "core group of experts" of which 20 were affiliated to Western institutions, two to the ICRC, one to a Chinese university. Further involved was a group of government experts representing seven Western states and a group of occasional participants of which four were affiliated to Western institutions, one to the ICRC and one to a military in Sub-Saharan Africa. See HPCR Commentary, pp. 8-11.

${ }^{20}$ HPCR Commentary, p. 92.

${ }^{21}$ I am aware of only one IHL scholar proposing a "mathematical" expression of proportionality. Javier Guisández Gómez suggests a proportionality index (PI) relating military advantage (MA) to collateral damage (CD) as follows: PI = MA/CD. He refrains from any indication of how to put numbers on MA and $\mathrm{CD}$. For this reason already, his text is unfit to underpin any quantitative proportionality modeling. Javier Guisández Gómez, 'El Principio de la Proporcionalidad y los Daños Colaterales, un Enfoque
} 
mystery would inhabit targeting law. As they confess themselves to black-letter law, the authors of the HPCR Manual should appreciate this. ${ }^{22}$

The question imposes itself with some weight because we have evidence that military commanders do use casualty estimates in their efforts to understand the implications of the proportionality principle. David Reisner, then commander of the International Law Department (ILD) at the Israel Defense Forces, has described a 2002 meeting on the laws of war in situations of targeted killings. ${ }^{23}$ ILD staff present at the meeting was asked to write down the number of 'Palestinian bachelors' in the age span of 18 to 45 who had to die so as to avert a terrorist attack from a 'Palestinian male bachelor' that was certain to kill one Israeli male aged between 18 and $45 .^{24}$ Answers ranged from zero to 'as many as needed' and the journalists reporting Reisner's account added that '[m]aybe it is not surprising that the outcome generated by the question was an irrational number'.

Reisner relates that his response was two people. If you formulate the question differently and ask whether I agree to sacrifice an Israeli man for three Palestinians, the answer might be different, but eight, for example, doesn't seem right to me. I learned a few things from that exercise: that young people tend toward higher numbers than older people, that people with families tend to give higher numbers than bachelors, that a correlation exists between political outlook and the number given. In the Shin Bet security service, by the way, there are those who say zero. I don't know what the right answer is, but I know that the question has to be asked before an attack. If the commander

\footnotetext{
Pragmático’ in Rafael Prieto Sanjuán, Conduccion de Hostilidades y Derecho Internacional Humanitario, Bogotá (2007), pp. 197-243.

${ }^{22}$ The HPCR Commentary explains the content of the HPCR Manual. The HPCR Manual's rules are designated as 'Black-letter rules' (HPCR Manual, p. iv). Given the almost total dominance of Western experts in the process, I would think that a more modest term would have been called for, especially if account is taken of article 38.1.d of the ICJ Statute.

${ }^{23}$ Yotam Feldman and Uri Blau, 'Consent and Advise' Haaretz 29 January 2009 (no longer available on the Haaretz website).

${ }^{24}$ The reduction of the case to Palestinian males of a certain age span reflects that the numerical approach needs to discard all complicating contextual factors. Considering the sacrifice women, children, elderly or infirm persons, or any constellation of them together with males of optimal age for military service, might have made the 2002 exercise more realistic - and altogether impossible. I simply cannot imagine ILD staff individually drawing up different columns for different categories men, women, children, elderly persons, infirm persons and so on, sub-divided into age cohorts - to then fill them with all conceivable number combinations for sacrificable individuals across these categories. Taking the numerical approach seriously instils a sense of its blasphemous character. As Anne Orford stated: 'The decisions and scholarly articles and books and treaty provisions expressing their faith in arithmetic and risk assessment and the possibility of evaluating and exchanging things that are substitutable one for the other are communicated through language. Language exceeds calculation, and reaches out to that which is singular and unique even in the calls for measurement.' Anne Orford, 'Trade, Human Rights and the Economy of Sacrifice', 18 Leiden Journal of International Law, pp. 179213 (2005), p. 213.
} 
asked the question and answered it based on a test of reasonableness; the task of the legal expert has been fully carried out. ${ }^{25}$

As Reisner describes the process, no colleague or external observer can test the reasonableness of the commander's answer to the numerical question. It would therefore be a test of the commander's intuitive reason only, as opposed to reason built on the reflexivity that human interaction provides. So the operation of the proportionality principle would seem to be wholly internalized into the mind of the military commander. The quantitative testing Reisner relates is best understood as a conditioning of the responsible commander's mens rea. She or he may then argue that their decision was based on legal advice that fully applied the proportionality principle. As far as I understand it, this application of the proportionality principle is tantamount to a prayer. For a formalist inquiry into proportionality in IHL, the quantitative approach mirrored in this particular ILD practice is not helpful at all.

Another conceivable explanation for the averseness to quantitative approaches to proportionality in IHL doctrine is rooted in the difficulties in measuring not so much the estimated civilian harm, but the anticipated military advantage. Surely, quantities and algorithms play a prominent role in attempts to identify the enemy in the Afghan counterinsurgency, which the U.S. Army tracks inter alia by means of social networking analysis. ${ }^{26}$ Yet on the overarching question whether a military operation is achieving its overall objectives (“are we winning the war?"), my initial assumption that advanced militaries are operating advanced assessment methods, was plainly wrong. Indeed, quantitative approaches to assess military operations are used, and attempts are made to aggregate them into an overall picture of the success or failure of the campaign as it stands. But we have scholarly testimony from inside the U.S. military that these so-called "operations assessments" are woefully defective as to their metrics, mathematics and reliability. In two articles published in the Autumn 2011 issue of the Naval War College Review, Dr. Jonathan Schroden and professor Stephen Downes-Martin analyse operations assessment practices based on their firsthand experience and observations during current U.S. military operations in

\footnotetext{
${ }^{25}$ Ibid.

${ }^{26}$ One example is the use of computer software by the U.S. Army to speed up the identification of important persons in Afghan insurgents' social networks. See

http://www.army.mil/article/38497/Social Networking The Silent Counterinsurgent/ (accessed on 24 September 2012).
} 
Afghanistan. ${ }^{27}$ Both articles suggest that one of the most advanced militaries is simply unable to understand what its operations on the Afghan battlefield are achieving. Downes-Martin lists “overoptimism”, "promiscuous metrics collection”, “junk arithmetic", "simplistic color coding" in graphical presentations of achievements and "logic failures" amongst the factors leading to the overall fiasco of operations assessments. ${ }^{28}$ Problems will multiply as the volume of data collected by a broad variety of sensors grows exponentially. ${ }^{29}$

All this would seem to raise serious questions about the U.S. military's capability to assess "military advantage" under the proportionality norm in IHL. As military advantage is understood, in IHL doctrine, to relate to the campaign in its entirety, and not only to single attacks, it would appear indispensable to have an idea of what does, and what does not further the achievement of the campaign objectives. Without functioning operations assessments, the military commander cannot relate expected civilian losses to assumed military advantage under IHL, simply because the military advantage of a specific attack is unknown to her or him. ${ }^{30}$

So one explanation for the reluctance of IHL scholars to endorse "mathematical models" or quantitative approaches would be that current militaries remain practically unfit to implement such models. I doubt whether this is a satisfactory explanation in its own right. Rather, I think that the intuitive rejection of mathematical proportionality calculations by IHL writers points us towards the very roots of the concept of proportionality. I find it indicative that the IHL writers I referred to reject a quantitative approach yet fail to point out alternative methods of determining excess. In doing so, they are invariably writing in the tradition of negative theology; a tradition that assumes the unknowability of the Creator to human beings. IHL scholars maintain their allegiance to the norm on proportionality, I think,

\footnotetext{
${ }^{27}$ Jonathan Schroden, 'Why Operations Assessments Fail. It's Not Just the Metrics', 64 Naval War College Review (Autumn 2011), pp. 89-102 and Stephen Downes-Martin, 'Operations Assessments in Afghanistan is Broken. What Is to Be Done?', 64 Naval War College Review (Autumn 2011), pp. 103126. The public domain literature on operations assessment is rather limited. I have been unable to find texts taking issue with Schroden's and Downes-Martin's arguments.

${ }^{28}$ Downes-Martin, supra, pp. 107-112.

${ }^{29}$ On 29 March 2012, the U.S. Defense Advanced Research Projects Agency (DARPA) issued a call for the mathematics, computer and data visualization communities to put forward proposals that allow the Department of Defense to meet the challenges of massive increase in data to be transformed into 'actionable information'. Available at http://www.darpa.mil/NewsEvents/Releases/2012/03/29.aspx (accessed on 1 October 2012).

${ }^{30}$ Somewhat surprisingly, state obligations under IHL turn out to be an argument for radically improving operations assessment methods and practices in the U.S. military. It illustrates how well IHL converges with the logic of military planning, but also how much the reality of military planning is lagging behind its own logic.
} 
because they consciously or unconsciously hold that its discontents (such as incommensurability of values and the subjectivity of judgment) are sublated by a normative content underlying the texts of IHL law. If that is correct, the proportionality principle is not just another tool to shift power over life and death to the military commander by fiat of the law. Rather, it is the norm in IHL perhaps closest to and most revelatory of the metaphysical presuppositions of IHL. It should be studied rather than denounced.

Silent enim leges inter arma $^{31}$ is commonly misunderstood as stating that the law is mute when arms are raised, its muteness signifying that violence is not regulated by the law at all. Yet the law is not mute, but silent. It holds its full powers to intervene and exercises them through silence. To understand the silence of IHL in determining what is excessive violence is my task in the following.

\section{X.3. The First Reading: On Proportionality}

Let me briefly recapitulate some observations made in the previous section.

- The targeting process, of which the proportionality assessment forms part, is circular and iterative.

- The proportionality assessment is forward-looking. It is about potentiality.

- The proportionality assessment is for the reasonable military commander acting in good faith.

- Apart from identifying what belongs to the categories of civilian losses and of military advantage, IHL scholarship does not explain how proportionality assessments are to be proceduralized.

- Some IHL scholars claim that the proportionality assessment is subjective.

- Some IHL scholars claim that the targeting assessment seeks to relate incommensurable values to each other.

- Neither of the latter two claims nor a general agnosticism on the way in which proportionality is assessed keeps IHL scholars from expressing continued allegiance to the proportionality principle.

\footnotetext{
${ }^{31}$ Cicero, Pro Milone, Section 11. Cicero's defense speech for Milo, accused for murdering Clodius, is generally taken as the source for the phrase. From the wording of Section 11 in Pro Milone, it is entirely clear that Cicero did not make the point that Milo's presumed self-defence fell outside the law, but rather that the law's silence amounted to an outright permission to defend oneself against a plotter.
} 
In the following, I will take seriously suggestions that the norm expressed in Rule 14 CIHL and in correspondent treaty law is indeed a norm on proportionality. In contemporary legal discourse, proportionality reasoning is often understood as a balancing of two competing principles endorsing typecast interests. That approach is reductive. It emphasises the principles, and tones down what makes them relate to each other. It foregrounds the parts, and backgrounds the totality in which and through which they interact. It is horizontal and omits consideration of the vertical that is presupposed in weighing. The IHL scholars I referred to follow this pattern. Much text is devoted to what counts as collateral damage and as military advantage, while passages on the act of balancing itself and its presuppositions are short, trivial or both.

Maybe there are good reasons for this avoidance. In affirming the incommensurability of civilian loss and military advantage, the IHL scholars I quoted suggest that they find no common measure applicable to both. On this understanding, civilian loss and military advantage lack a third element to which and through which they can be related. In the end, one must be chosen over the other. ${ }^{32}$

The lexical root of 'proportionality' is the Latin noun proportio, which, in turn, is a translation of the Greek noun analogia ( $\dot{\alpha} v \alpha \lambda o \gamma i \alpha) .{ }^{33}$ To deal with something ana logos means to deal with it according to a due logos, and it merits emphasis that the Greek ana literally means 'up to, ${ }^{34}$, implying a vertical relationship. The $\dot{\alpha}$ in $\dot{\alpha} v \alpha \lambda o \gamma i \alpha$ (analogia) indicates the 'first', the entem, the pure essence, while the $v$ (n) indicates that the two entities ontologically share a common origin. ${ }^{35}$ Traditionally, lawyers use the terms 'analogy' when reasoning on relevant commonalities of two cases $^{36}$, while they use 'proportionality' when reasoning on the relative weight of conflicting principles ${ }^{37}$. Yet in doing so, they invariably draw on one and the same conceptual tradition, in which the whole is represented through its parts.

\footnotetext{
${ }^{32}$ In the Greek language, this would be an antalogia, not an analogia (the prefix 'ant-' signifying 'instead'). I am indebted to Luca Bonadiman for explaining this to me. Keeping within the tradition of proportionality perforce implies that the weight of one of two countervailing principles never can be zero.

${ }^{33}$ Entry on 'proportion', Georges, Ausführliches lateinisch-deutsches Handwörterbuch, Hannover (1913).

${ }^{34}$ Entry on 'analogon', Oxford English Dictionary, $2^{\text {nd }}$ ed., Oxford (2009).

${ }^{35} \mathrm{I}$ am indebted to Luca Bonadiman for pointing this out to me.

${ }^{36}$ The issues related to this important aspect of analogy are dealt with in David Reidhav, Reasoning by Analogy - A Study on Analogy-Based Arguments in Law, Lund (2007), available at http://en.scientificcommons.org/21998869 (accessed on 1 October 2012).

${ }^{37}$ The standard reference is Robert Alexy, Theorie der Grundrechte, Frankfurt (1994).
} 
In the original Greek sense, analogy involved a comparison of two proportions or relations. Thus 'principle' was said to be an analogical term when said of a point and a spring of water, because a point is related to a line as a spring is related to a river. This type of analogy came to be called the analogy of proportionality. ${ }^{38}$

Reading this brings me back to the incommensurability of civilian loss and military advantage that IHL scholars have given voice to. Is it not possible that these worries stem from an error in imagining their relation? It could be simply wrong to imagine civilian loss and military advantage to be directly related to each other. The analogy of proportionality is but the relation of a relation. Rather, drawing on the original Greek analogy of proportionality, it might be that civilian loss is related to a certain element just in the same way as military advantage is related to a certain element.

Does this help? It does in that it might do away with the concern of incommensurability in the IHL proportionality assessment. It also incites me to imagine the relata of civilian loss and of military advantage. And what term will take the place of the 'principle' in the example quoted above? How shall I properly understand and denote that which is analogous in a proportional sense?

The latter two questions emphasize the point where all relations ultimately converge. They invite me to add another form of analogy to this text. ${ }^{39}$ The analogy of participation is about a relation of likeness between creator and creation. This form of analogy remains a topos for theologians contemplating the relation between God and God's creation. When introducing the analogy of participation, I would like to retain the possibility of alternating between an outspoken theological approach (from which I hope to glean systematicity at the very least) and a quasi-secular one, in which international relations are assumed to be a key factor in shaping reality (which is obviously closest to my empirical material of warfare and IHL). By operating the analogy of proportionality and the analogy of participation alongside each other in this text, I hope to integrate horizontal as well as vertical aspects of the issue of proportionality in IHL.

At the point where the relation between civilian loss and military advantage is assessed as proportionality, we are given over to our assumptions on being at large.

\footnotetext{
${ }^{38}$ E. Jennifer Ashford, 'Medieval Theories of Analogy', in Stanford Encyclopedia of Philosophy, available at http://www.science.uva.nl/ seop/entries/analogy-medieval/ (accessed on 6 August 2012).

${ }^{39}$ For the record, a frequently discussed type of analogy omitted here is the analogy of attribution, which relates two things to each other when a primary thing contributes to or causes a secondary thing.
} 
Here are three choices. The being of beings can be cast as totally different, merely converging on the use of one and the same word. This is called aequivocatis entis voicing the word 'being' on something similar, but ultimately different. In law, this understanding is present in the postmodern belabouring of law's indeterminacy. Or indeed, in the other extreme, beings converge substantially in being. This is univocatis entis - voicing the word 'being' indeed denotes something identical to us all. The universality of human rights as cast in advocacy discourses is perhaps the most straightforward example here, but some might think of 'humanity' outright. ${ }^{40} \mathrm{~A}$ middle way between total difference and total identity is to understand my own being as analogous to that of other beings. What I then have in common with others is a relation, and this relation is the third that we have in common. This choice is termed the analogy of being - analogia entis.

Do military commanders and civilians have something in common? In order to make sense of the proportionality principles in IHL, I have to assume that they are capable of establishing a common logos. Provided I assume that, the due logos of the relation between the military and the civilian will always be an onto-logos, a logos of being at large. There is no proportionality assessment without its implied ontology.

First, I found it difficult to relate the analogia entis to international armed conflict, until I allowed myself to think of the creator, of being and of sovereignty as operating on the same level, albeit each in their respective disciplines of theology, ontology and international law. Put differently, a creator may figure as a sovereign as much as the divine, the former in the realm of international legal scholarship, and the latter in the realm of theology. Sovereignty is distributed relationally in a certain understanding of international law, as is the divine in certain forms of theology or as is being in certain forms of ontology. Analogia entis is the structure common to all three, working vertically (erga omnes, as international lawyers would say) as well as horizontally (inter partes).

\footnotetext{
${ }^{40}$ In her intriguing 2009 EJIL article, Professor Anne Peters has superimposed humanity over sovereignty to argue for an international law centred on the individual (and for outlawing the vetoing of 'proportionate humanitarian action to prevent or combat genocide or massive and widespread crimes against humanity'). Anne Peters, 'Humanity as the A and $\Omega$ of Sovereignty', 20 EJIL pp. 513-544 (2009). I must concede that I have difficulties with this argument. The reference to proportionality and the idea of steady progress in 'humanizing' international law make me think that this type of argument stealthily assumes 'humanity' to be structured as Trinitarian divinity, bringing us ever closer towards a full revelation of what is human - indeed the second coming of Christ.
} 
Why is analogia entis helpful in the IHL context? Targeting considerations are about the relation of the potential with the actual. In the moment of targeting, I encounter two conflicting parties before an attack takes place, that is, in a moment before a potential actualizes. This potential is kinetic as much as political. ${ }^{41}$ It can bring down buildings and hurt humans as much as it can alter articulations of political will. An attack affecting civilian life or property is interacting with the articulation of political will of the attacked party in a special way. The topos of morale bombing is only the crudest form of this line of thought, which may also be cast in the form of democratic process or of volonté générale. For the moment, it is not important which of these I choose.

The same goes for the attacking party. Under IHL, an attack is performed in pursuit of military necessity, that is, a necessity flowing from the attacking party seeking to actualize the potentiality of its will. So on the sides of both parties an attack creates relations between will and reality, between potentiality and actuality. As warfare is an iteration of attacks, this process is iterative, which emerges not least from cyclical depictions of the targeting cycle in military doctrine. This dynamic is important, as I will argue later on.

I shall go a step further. Here is my tentative formulation of the structure of proportionality in IHL targeting norms:

On the side of the attacking party, there is a relationship between sovereign potentiality and sovereign actuality that is analogous to the relationship between sovereign potentiality and sovereign actuality on the side of the attacked party. Maintaining an attack and, in particular, its effects on civilian life, within that analogous relationship preserves the relation between sovereign potentiality and sovereign actuality with the attacked. An attack that moves beyond this analogy is disproportional, because it looses touch with the relation of potentiality and actuality of the attacked party's will-formation.

Let me briefly exemplify with the use of nuclear weapons in defence of the existence of a state as the embodiment of the sovereign. Drawing on the structure of analogia entis, it appears arguable that an attack on a state so large that it would lead to its annihilation (whether militarily conventional, nuclear or other) derails completely the relation between potentiality and actuality in the sovereign willformation of the threatened party. This could be the reason why the Advisory Opinion

\footnotetext{
${ }^{41}$ And it is ultimately springing forth from the demos, as I will argue in Section 4 below.
} 
of the ICJ controversially left room for this particular use of nuclear weapons in selfdefence. I emphasize the subjunctive here: my point is to present analogia entis as a relevant form of thought, not to legitimize this particular position of the ICJ.

At this point, I want to introduce the writings of the German Jesuit theologian Erich Przywara. His main work Analogia Entis ${ }^{42}$ lives off his ability to foreground and detail the rhythmical, dynamical structure of the analogy of being, which he roots in the traditions of Thomism and negative theology. Przywara's philosophical credentials are quickly sketched: his thought was shaped by phenomenology and he engaged in personal exchanges with Edmund Husserl and his circle, with Martin Heidegger and with Edith Stein.

Why move Przywara's work into IHL? In my tentative formulation above, there is a dynamic in the will of the parties, yet the analogy I make comes across as static, as if frozen into a photograph. What is beneficial in Przywara's thought is his capability to explain the analogy in a way that makes me grasp its drivers and motions, its rhythmic dynamism.

The key to Przywara's analogy is the idea of the creator being in-and-beyond his or her creatures. To be extremely clear on this point, creation is no on off affair, in which the creator does his or her job to then withdraw and let creatures sort out life by themselves. In that sense, creation is going on, actualizing, through creaturely life. And, I should add, so is revelation.

The central element with Przywara's thought is a thomistic differentiation between essence (essentia) and existence (esse). ${ }^{43}$ Both are separated in creatures, but coincide in God. If I then recall another thomistic teaching to the effect that potency is pushing towards actuality, the drama in Przywara's explication becomes apparent: the analogy of being starts to move and keeps itself within an incessant cyclical movement towards the actualization of potency. Negation is the true driver, a negation that is ultimately due to the unknowability of God. While essence and existence constitute a unity, it is one characterised by their tension. ${ }^{44}$ It is because

\footnotetext{
${ }^{42}$ Erich Przywara, Analogia Entis. Metaphysik. I Prinzip, Munich (1932). A revised and expanded version was published as Analogia Entis. Metaphysik. Ur-Struktur und All-Rhythmus, Einsiedeln (1962). A translation into English by John R. Betz and David Bentley Hart is forthcoming.

${ }^{43}$ Thomas ab Aquino, On Being and Essence [De Ente et Essentia], [translation by Robert T. Miller] (1997), available at http://www.fordham.edu/halsall/basis/aquinas-esse.asp\#fl (accessed on 1 October 2012).

${ }^{44}$ Przywara's term for this phenomenon is 'Spannungseinheit', translated by Betz as 'unity-in-tension'.
} 
essence and existence only coincide in God that this movement will go on and on incessantly in time.

Creation and revelation are simultaneously driven and limited by analogy, or, as Przywara puts it:

Das Erkennen des Seins geschieht nur analog: die Aussagekraft der Erkenntnisse wird relativiert durch ihre Nichtaussagekraft, wie es in der Formel des IV. Laterankonzils von 1215 heißt: "inter creatorem et creaturam non potest tanta similitudo notari, quin inter eos maior sit dissimilitudo notanda“. ${ }^{45}$

Actually, we are faced with a double analogy in the relational space of the inand-beyond: the essence of creatures is in-and-beyond their existence just as God is in-and-beyond creation. ${ }^{46}$ John. R. Betz explains the differences and similarities between the creator and human beings as creatures:

To be sure, creaturely being is similar to God by virtue of its participation in God's Being; otherwise it would not "be" at all. But it remains fundamentally more dissimilar given not only that its being is given, but that God "Is" who he is (Exod. 3:14), whereas creatures are forever becoming who they "are". Thus, following Aquinas, Przywara emphasizes that any participation of creaturely being in God's Being is ultimately not according to a direct proportion (analogia proportionis), whereby the creature's essence participates directly in the essence of God (in the manner, say, that 1 is related to 2), but according to an indirect relation of proportionality (analogia proportionalitatis), whereby the relation of essence and existence in creatures is analogous to the relation (or rather identity) of essence and existence in God (in the manner, say, that 6 is indirectly related to 4, viz., as, respectively, $2 \times 3$ and $2 \times 2){ }^{47}$

There are a number of things to note. First, with Betz, I observe how Przywara operates the analogy of proportionality within the analogy of participation in his structure. It is noteworthy that the legal discipline speaks not of a "principle of proportion" when balancing principles, but of a "principle of proportionality". This terminology turns out to be adequate once a thomistic perspective is adopted. Second, Betz' remark that 'God "Is" who he is [...] while his creatures are forever becoming

\footnotetext{
45 'The cognition of being happens only analogously: the power of significance of findings is relativized by their power of non-significance, as is stated in the formula of the Fourth Lateran Council of 1215: "inter creatorem et creaturam non potest tanta similitudo notari, quin inter eos maior sit dissimilitudo notanda".' (my translation). The Latin excerpt from the Fourth Lateran Council's Second Canon reads as follows in English: "between the Creator and the creature there cannot be a likeness so great that the unlikeness is not greater." The Canons of the Fourth Lateran Council, 1215, available at http://www.fordham.edu/halsall/basis/lateran4.asp (accessed on 9 August 2012).

${ }^{46}$ John R. Betz, "Beyond the Sublime: The Aesthetics of the Analogy of Being (Part One), 21 Modern Theology, pp. 1-50 (2004), p. 29.

${ }^{47}$ Betz supra note 39, p. 29. Brackets and emphasis in the original.
} 
who they "are"' became more poignant when I understood that the 'be' is associated with God, the 'being' with the human and the 'becoming' with the Holy Spirit. ${ }^{48}$

This brief consideration of Przywara's work leads me to a question to international law. Is there an unacknowledged thomistic debt in the form that the international law of proportionality has taken? Could it still be the case that secular international law reproduces this fundamentally Roman-Catholic form of thought? ${ }^{49}$ In my tentative formulation above, I have used the term 'sovereignty' as an indeterminate third. The question is now whether it not only operates on the same level as God in Przywara's Analogia entis, but according to the same pattern.

Let me consider a military conflict from the perspective of the attacking party. Warfare is 'ein Akt der Gewalt, um den Gegner zur Erfüllung unseres Willens zu zwingen ${ }^{50}{ }^{50}$ We see the 'act of violence' originating in 'our will', which attains a considerable, and considerably dangerous, theological significance if the state is directly related to the divine will of the creator. This existential act of violence is negated by the attacked party; indeed, negated repeatedly. This, in turn, entails the cyclical movement of 'the targeting circle'; consisting of targeting, attacking, assessing effects and renewed targeting. ${ }^{51}$ This circle is concurrently a movement from the potentiality of sovereign will towards its actualization in a sovereign act of violence. I like to think that it is this particular instance of 'in-and-beyond' and the dynamics it unfolds that makes sovereignty such an 'unavoidable' concept in international law. The unknowability of the precise workings of proportionality in IHL participates in the unknowability of sovereignty, which, in turn is grounded in the unknowability of the creator. So the agnosticism of the IHL authors I adduced is, after all, explainable, and the perplexity on the incommensurate relationship between military advantage and harm to civilians is dissolved. Either the will of the attacker is

\footnotetext{
${ }^{48}$ At this bewildering intersection, thanks are again due to Luca Bonadiman, who translates God's

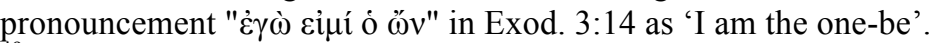

${ }^{49}$ The Catholic Church has invested itself heavily into thomism in general and the analogia entis in particular. Pope Pius X has declared the capital teachings of Thomas ab Aquino to be 'the foundations upon which the whole science of natural and divine things is based' and therewith beyond debate (Encyclical Doctoris Angelici, 29 June 1914), while Pope Benedict emphasizes that the Church has always insisted on an analogical relation between God and human beings in his Regensburg address of 12 September 2006 (paragraph accompanying supra note10).

${ }^{50}$ Carl Clausewitz, Vom Kriege, Berlin (1832), Buch 1, Kap. 1, In. J.J. Graham's 1873 translation, this is adequately rendered as 'War therefore is an act of violence to compel our opponent to fulfil our will.' Carl Clausewitz, On War, [translated by J.J. Graham], London (1873).

${ }^{51}$ In military contexts, targeting is usually depicted as a circle of events, with the commander's objectives being placed at the top. Targeting circles always move cyclically from objectives over targeting and actual infliction of violence on to the assessment of results, which then serve to inform the commander's objectives.
} 
seen as a purely human disposition, in which case it is purely existential, thereby cutting all relations with the essence of the creaturely civilian. Or the will of the attacker is seen as a manifestation of divine will, in which case it is not part of the creation in the same way as the creaturely civilian. Indeed, the incommensurability critique emerges in a sharper light in the politico-theological dimension.

To be sure, any military commander who reflects on the thomistic roots of proportionality will realize that a divinely rooted sovereignty cannot be thought as something residing merely in the nation state which he or she happens to serve. Then again, I have to admit that the widespread agnosticism on the procedure to use in proportionality assessments in IHL doctrine might combine fatally with a culture of obedience and loyalty to that state. If a commander identifies sovereignty as residing solely within her or his own state for the purposes of analogical thinking, this will result in a paternalistic treatment of expected civilian casualties in the most proper and terrifying sense of the word. In a Trinitarian mode, the state would be absurdly elevated to the level of God the creator, the people of that state, including its military, would assume the role of the Holy Spirit, and the remainder of the world's population that of man to whom truth is gradually revealed.

It goes without saying that this interpretation would be a fatal misunderstanding of analogical thinking. It would do away with the horizontal dimension entirely, in which human is equal to human. With that, it would obviate any idea of an international community in which IHL might still be implemented.

\section{X.4. The Second Reading: Demos and Polis}

As soon as I permit myself to put sovereignty in the place of the creator, and therewith assume the place of one common third, things get to be interesting. The state's essence is in-and-beyond its existence, and sovereignty is in-and-beyond the state. Or, in another key, sovereignty is intra-statal and para-statal at the same time. This destabilizes and mobilizes the concept of sovereignty.

The decision on targeting is said to be for the 'reasonable military commander', required to act, as it were, 'in good faith'. What, then, is the proportionality principle obliging that commander? It is an obligation to preserve the attacking party's conduct within the analogia entis. What does that mean? The attack must not have such consequences so as to arrest the relationship between essence and existence played out through the other party. Why is this important? If we accept that 
sovereignty is distributed, there is no fully unilateral sovereign act. The actualizing of sovereignty is never that of one party to the conflict alone. To deny the actualizing of the opposed party's sovereignty, is to foil the actualizing of one's own sovereignty. The attacking party's sovereign potentiality can only actualize in the world through negation. The attacked counterpart is one source of such negation. Therefore, it is needed for sovereignty to actualize through the conflict as much as is the attacking party.

What is the particular form of reason required of the 'reasonable military commander'? Proportionality determination in IHL assumes two related capabilities: that of sensing and that of making sense. Sensing means to open up towards and perceiving all givens that relate to prospective civilian loss and military advantage. At a certain point, this shifts into making sense of all these givens as to whether or not they suggest an excess of civilian loss. The Greek term aesthesis denotes these two: sensing and making sense. In relating these to each other, three choices open up. In the first, the faculty of making sense - that is, knowledge - dominates the faculty of sensation - that is, desire. By way of example, if we know that military necessity is the end of IHL, we will subordinate sensations of compassion, repulsion or disgust to that knowledge. In the second, the faculty of sensation dominates the faculty of making sense. By way of example, a sensation of empathy might make us forgo an action that we know to be permitted by the law.

As Jacques Rancière points out, drawing on Kant's Critique of Judgment, there is a third choice, in which a phenomenon is seen and appreciated

neither as an object of knowledge nor as an object of desire. In this case, neither faculty rules over the other; the either/or no longer works. The two faculties agree with each other without any kind of subordination. ... What is at stake here is the specificity of a distribution of the sensible that escapes the hierarchical relationship between a high faculty and a low faculty, that is, escapes in the form of a positive neither/nor. ${ }^{52}$

And Rancière goes on to add that ' $[\mathrm{t}]$ his rejection of the hierarchical relation between the faculties that make sense involves a certain neutralization of the social

\footnotetext{
${ }^{52}$ Jaques Rancière, 'The Aesthetic Dimension: Aesthetics, Politics, Knowledge', 36 Critical Inquiry, pp. 1-19 (2009), pp. 1-2.
} 
hierarchy'. ${ }^{53}$ The power to negate the pre-existing hierarchical ordering of the sensitive is central, as it is in Przywara's analogia entis.

What I call the aesthetic dimension is this: the count of a supplement to the parts that cannot be described as a part itself. It is another kind of relation between sense and sense, a supplement that both reveals and neutralizes the division at the heart of the sensible. Let us call it a dissensus. A dissensus is not a conflict; it is a perturbation of the normal relation between sense and sense. ${ }^{54}$

For sure, the dissensus is in-and-beyond. Here is where Rancière's aesthetics and those of the analogia entis appear as structurally identical in that they rest on a third, perform negation and revelation, and always reach beyond that which is known about the sensible. Rancière emphasises that the neutralization is 'not at all tantamount to a pacification', rather, it brings about 'a more radical way of seeing the conflict'. ${ }^{55} \mathrm{He}$ contrasts the aesthetical dimension to that of the ethical, commonly associated with the humanitarian ethos of IHL. It is helpful to recall, with Rancière, that ethos 'first meant abode before it meant the way of being that suits an abode'. ${ }^{56}$ An ethics of humanitarianism cannot avoid localization in one particular community. In the case of the proportionality principle in IHL, it will invariably be the community of the deciding military commander.

The proportionality principle accords hierarchical supremacy neither to perception nor to knowledge. If perception were to rule, there would be no "reason" at work in the commander, and if knowledge were to rule, we could expect to have more detailed and explicit rules on how to determine proportionality. I think that what I have described as "agnosticism" in the IHL literature is, in the best scenario, a sign of a rejection of a hierarchical relation between sensibility and knowledge. IHL scholars emphasise this suspension when they write that the commander must be reasonable (thus drawing on her faculty of knowledge) and in good faith (thus giving herself over to a particular form of impassioned sensibility).

Analogia entis as a form of thought is staged in aesthetics. On its thomistic roots, Davies writes: '[p]roportionality secures the structure of interaction and participation, in which one element reveals another and the whole comes into view in

\footnotetext{
53 Ibid.

${ }^{54}$ Rancière, supra, pp. 2-3.

${ }^{55}$ Rancière, supra, p. 3.

${ }^{56}$ Ibid.
} 
its parts (the very essence of aesthetic perception). ${ }^{57}$ The suspension inherent in the analogia entis 'can be said to transmit or mediate the light of transcendence', and grounded in a notion of being as the beauty or likeness of God. ${ }^{58}$ Its aesthetics would be 'dissensual' in that it accords hierarchy neither to perception nor to knowledge. This is not to suggest that Rancière and Przywara are in agreement on aesthetics. Yet their differences are less important for the moment. The point is that both help me transgress a perspective on sovereign violence that can only take account of sovereignty (or humanity, or any law of the ethos) as that of one state, or one conflicting party, at a time.

Concluding on Przywara and Rancière so far, the reasonable military commander acting in good faith is suspended between knowledge and passion, between potentiality and actuality, between being and non-being. Structurally, she negates the separation of both parties to the conflict in the dimension of the analogical and dissensual. In performing such a proportionality assessment, she is no longer fully subsumable as a representative of the attacking party, i. e. the nation state to which she has sworn allegiance.

Without empirical research on the performance of targeting and proportionality assessments, I cannot know whether the structure of analogy and dissensus actually informs military commanders. It cannot be excluded that what comes across as the agnosticism of IHL doctrine dominates and sets free an unreflected decisionism. This decisionism will invariably draw on ethics as a law of the abode. It will maximize the sovereign interests of the attacking party, because it can only relate to sovereignty as being that of one particular state. Yet the converse is true, too. Without empirical research, I cannot positively claim that targeting is structurally unrelated to analogia entis and dissensus, or is but their perversion.

To relate essence and existence to each other in the context of armed conflicts also means to relate the demos as the source of sovereignty to the particular stateform it has taken. If the proportionality principle prohibits the disruption of the relationship between sovereign potentiality and sovereign actuality, it will invariably

\footnotetext{
${ }^{57}$ Oliver Davies, 'Von Balthasar and the Problem of Being', 79 New Blackfriars pp. 11-17 (1998), p. 11.

${ }^{58} \mathrm{Ibid}$. It is worth recalling that man being created 'in the image of God' was precisely the point of departure for Kooijmans reconstruction of equality in international law. See text accompanying supra note 2 .
} 
prohibit the disruption of the relationship between the potentiality of the demos and its actuality.

I want to intersperse three empirical observations here. First, I recall that international law, since the inception of natural law, has needed the enemy demos in in order to terminate wars in Europe. Pufendorf, casting the enemy as a justa hostis, a just enemy, suggests that wars against it will be brought to end by a peace treaty or by conquest rather than by annihilation. ${ }^{59}$ Both forms of termination pivot on the preservation of the enemy's will power. In the latter case, termination presupposes that enemy subjects swear an oath of fidelity to the conqueror. This is perhaps the most apt illustration of how the corpus mysticum of sovereignty is preserved even in the most existentially threatening situations, where the corpus naturale of the state is consumed. ${ }^{60}$

Here is my second observation. In IHL, civilians appear as unqualified civilians. The proportionality rule relates not to 'enemy civilians', but to civilians at large, regardless of nationality or political allegiance. From a literal reading of article 51.5.b API, this would already be evident, at least since the text of that Protocol was opened for signature in 1977 (two years, I note, after the termination of a conflict for the 'hearts and minds' in Vietnam). Currently, IHL experts tend to emphasize this issue, very likely due to a mainstreaming of asymmetrical warfare, where the civilian on an embattled territory is no longer necessarily an enemy civilian, but rather a person for whose heart and mind the battle is fought. ${ }^{61}$

Third, it strikes me how challenging the issue of civilian staff working at military installations is for contemporary IHL commentators. One group proposes to

\footnotetext{
${ }^{59}$ On the question of conquest, Pufendorf writes: 'Empire also or Government comes to be acquired by War, not only over the particular or single Persons conquered, but entire States. To render this lawful, and binding upon the Consciences of the Subjects, it is necessary, That on the one Side the Subjects swear Fidelity to the Conqueror; and on the other, that the Conqueror cast off the State and Disposition of an Enemy towards them.' Samuel Pufendorf, The Whole Duty of Man, Indianapolis (2003), p. 243 (footnotes omitted).

${ }^{60}$ Ernst Kantorowicz famously introduced the argument that the theological conception of the Church as a corpus mysticum migrated first into the King and then into the secular state. Ernst Kantorowicz, The King's Two Bodies. A Study in Medieval Political Theology, Princeton (1957), in particular Chapter V.

${ }^{61}$ That said, the U.S. counterinsurgency doctrine appears to reverse the IHL assumption that persons lacking combatant characteristics are to be taken as civilian. The counterinsurgency logic is one where humans need to qualify as civilians, rather than to be assumed as being civilians in the absence of further qualifications. Amin Parsa's work on counterinsurgency and IHL has alerted me to these issues. On the transformation of war and of the civilian-combatant dichotomy, Nathaniel Berman's, 'Privileging Combat? Contemporary Conflict and the Legal Construction of War', 43 Colum. J. Transnat'l L. 1 (2004-2005), pp. 1-72, remains instructive.
} 
omit this group of civilians from proportionality balancing, ${ }^{62}$ which would expand the category of permissible attacks under IHL. ${ }^{63}$ As military tasks have been increasingly privatised in the West over the past decade, Western states could be expected to push for the inclusion of civilian staff in proportionality balancing as civilians. It is significant that this interest does not seem to reverberate through IHL scholarship.

The second observation suggests that the protected demos is a heterogeneous group of civilians rather than a polis organized qua citizenry. ${ }^{64}$ On the other side of the spectrum, the civilian serving a private military contractor is strongly institutionalized into the oikos (i.e. a community whose members may be excluded from the polis, although they remain included into the economy), even though she might not hold the citizenship of the state using the contractor's services. As the oikos has been increasingly targeted in contemporary armed conflicts (dual-use infrastructure attacked with kinetic means or within the framework of a cyberattack being a case in point), it is not surprising if civilian employees were to be leaving the domain of protection.

So the unqualified are important to preserve, whereas the qualified in the oikos and the polis ${ }^{65}$ become increasingly exposed to violence that is cast as legitimate. Recalling Clausewitz' dictum that wars are fought to compel the enemy to fulfil our

\footnotetext{
62 'Opinions in the Group of Experts were divided as to whether civilians who are physically within a military objective (e.g., civilian employees working in a munitions factory) count for the purposes of the application of the principle of proportionality. Three views were expressed. Some experts were of the opinion that such civilians do not count because they have chosen to be there and have thereby voluntarily assumed the risk of an attack by the enemy. The majority of the Group of Experts felt that the principle of proportionality applies to such civilians as in all other cases. However, some experts while belonging to that majority - pointed out that the application of the principle of proportionality will not make a material difference when the target is a high-value asset (such as a munitions factory), referring to the fact that extensive casualties do not necessarily amount to excessive collateral damage.' HPCR Commentary, pp. 93-94.

${ }^{63}$ I will mention below that the oikos is increasingly targeted in contemporary military campaigns. One could argue that coherence requires that the level of protection for persons working for military subcontractors would decrease even in other areas as the assessment of proportionality.

${ }^{64} \mathrm{Often}$, polis is understood as a community organized in a state. For the sake of simplicity, I shall us the term polis in that sense in the following. Let it be said that a polis can very well take another form than a state, and my observations would apply to it mutatis mutandis.

${ }^{65}$ Do civilians choosing to place themselves in the vicinity of military objectives (so-called 'voluntary human shields') count in the proportionality analysis? The expert group behind the HCPR Commentary was divided on the matter: 'There were three divergent views within the Group of Experts about the status of "voluntary human shields". One view was that voluntary human shields are not counted in the calculation of collateral damage because they are directly participating in hostilities. A second view held that voluntary human shields do not qualify as civilians directly participating in hostilities. Hence, they remain protected civilians who count fully under the proportionality analysis. ... Finally, the third view agreed with the second view as to the status of voluntary human shields, but asserted that the principle of proportionality will apply to them in a modified (more relaxed) way, since they have deliberately put themselves in harm's way in order to affect military operations.' HCPR Commentary, p. 144. (Footnote omitted).
} 
will, the question is why. One instrumental understanding of this dictum would suggest that the politically qualified, the elites, need to be spared, because they are institutionally most capable of fulfilling the victor's will. Those outside the elite could be sacrificed. This instrumental view would privilege the institutionalized and socially hierarchized polis over the demos of the unqualified. It would ignore the fact that the proportionality norm in IHL protects civilians without any further differentiation, which is already a sufficient ground to reject it.

To understand Clausewitz' dictum properly, I think we need to leave the actuality of the polis and move to the potentiality of the demos. Rancière describes the political as consisting of 'two antagonistic logics': one is the rule of oligarchic institutions (which he terms the 'rule of the police'), supplemented by a logic suggesting that 'the rulers rule on the ultimate ground that there is no reason why they should rule'. ${ }^{66}$ While the qualified do actually rule, they do so on the ground that anyone could rule. This is the democratic supplement. Rancière goes on to explain:

The power of the demos is the power of whoever. It is the principle of infinite substitutability or indifference to difference, of the denial of any principle of dissymmetry as the ground of the community. The demos is the subject of politics inasmuch as it is heterogeneous to the count of the parts of a society. It is a heteron, but a heteron of a specific kind since its heterogeneity is tantamount to substitutability. Its specific difference is the indifference to difference, the indifference to the multiplicity of differences — which means inequalities - that make up a social order. ${ }^{67}$

Quite obviously, this indifference to difference also comprises an indifference to citizenship. The demos is potentially negating its ties to the enemy state, which makes it reasonable to address it as a group of unqualified 'civilians' rather than of qualified 'enemy civilians'. Harming the unqualified demos in an attack means to harm as much the enemy demos as one's own demos. Also, it is the demos that has the potential to negate in every moment the will-formation of the qualified oligarchy of the polis. It is the unqualified, substitutable demos.

I have earlier argued that a proportionality assessment in targeting needs to preserve the relation between essence and existence, between potentiality and actuality. I would like to add now that it needs to preserve the particular

\footnotetext{
${ }^{66}$ Rancière, supra note 52, p. 11.

${ }^{67}$ Rancière, supra note 52, p. 10.
} 
supplementary and negating relationship between demos and polis, with the demos understood to be 'the uncountable count of the anyone' ${ }^{68}$

This transcendent move comes at the price of a movement towards immanence. The transcendent move can only be performed by a decision-taker who makes the tension between demos and polis into her own. The analogy of proportionality can only be performed if the decision maker understands the relation between the demos and polis of her own state as much as she understands the relation between demos and polis of the opposed party.

Yet the negating power of the demos does not stop at the border of nation-states, and neither does it stop at the doors of military institutions. ${ }^{69}$ In the structure that has emerged in my third reading, sovereignty is always distributed through the demos. If demos is taken to mean that anyone could rule, and that no one is unequal, the relation between the potentiality of the demos and its actuality in a presumed polis is disrupted already with the first civilian casualty. It continues to surprise me that IHL, for all its faults, contains an obligation on military commanders to contemplate exactly this.

\section{X.5 Negative Equality}

What I have done now is, I think, the utmost possible with an international humanitarian law that disavows its Christian substance, but remains Christian in form. Substituting God and the nation-statist sovereign for the demos might just make IHL less divine and more worldly. Central to this shift would be a reasonable military commander contemplating the unqualified demos. I think that any effort of this kind may mitigate the agnosticism and concomitant nation-statism of IHL.

That said, I would grant that the very same substitution might just make the demos less worldly and more divine. ${ }^{70} \mathrm{I}$ find it striking that Jacques Rancière's analogy of the demos is structurally all but identical with Erich Przywara's analogy of being. ${ }^{71}$ This is an indicator as good as any that analogical thought outside the

\footnotetext{
${ }^{68}$ Rancière, supra note 52, p. 11.

${ }^{69}$ It is a wholly different question whether the requisite immanence is at all possible in a form of warfare where much of the sensing is delegated to technology and much of the making of sense to algorithms.

${ }^{70}$ I am grateful to Daniel Steuer for alerting me to the possibility that Rancière's demos might introduce a 'negative absolute identity'. And, I should add, to the consequences that might entail for any attempt to think targeting analogically.

${ }^{71}$ Considering Rancière's explanation of the power of the demos accompanying footnote 67 above, its is easy to see that Rancière's dichotomy of indifference and difference restages the role played by
} 
Thomist form is not readily available to us here and now. Two things follow. First, a radically secular way of thinking targeting with Rancière's demos might just be as good - or as bad - as a radically Catholic way of thinking it with Przywara. However, any of the two are invariably better than what the current stasis of agnosticism and allegiance in IHL might bring about. What makes them better, and this is my second and last point, is that they open up those making decisions about targeting as 'reasonable military commanders' or international humanitarian lawyers at large towards an apophatic contemplation. Any third - creator, sovereign, demos or other will always be so unknowable as to deny me justification of my proportionality judgment under the law.

\section{References}

Robert Alexy, Theorie der Grundrechte, Frankfurt (1994)

Thomas ab Aquino, On Being and Essence [De Ente et Essentia], [ca. 1255] [translation by Robert T. Miller (1997)], at http://www.fordham.edu/halsall/basis/aquinas-esse.asp\#f1

E. Jennifer Ashford, 'Medieval Theories of Analogy', in Stanford Encyclopedia of Philosophy at http://www.science.uva.nl/ seop/entries/analogy-medieval/

Jennifer Beard, The Political Economy of Desire. International Law, Development and the Nation State, Oxon (2007)

Nathaniel Berman, 'Privileging Combat? Contemporary Conflict and the Legal Construction of War', 43 Colum. J. Transnat'l L., pp. 1-72 (2004-2005)

John R. Betz, "Beyond the Sublime: The Aesthetics of the Analogy of Being (Part One), 21 Modern Theology pp. 1-50 (2004)

William H. Boothby, The Law of Targeting, Oxford (2012)

The Canons of the Fourth Lateran Council, 1215, available at http://www.fordham.edu/halsall/basis/lateran4.asp

Cicero, Pro Milone

Carl Clausewitz, Vom Kriege, Berlin 1832

Oliver Davies, 'Von Balthasar and the Problem of Being', 79 New Blackfriars pp. 11-17 (1998)

Yoram Dinstein, The Conduct of Hostilities under the Law of International Armed Conflict, Cambridge, $2^{\text {nd }}$ ed., (2010)

Przywara's essence and existence. The indifference to difference of the demos is analogous with the identity of essence and existence in Przywara's Creator. Rancière's heteron is characterised by substitutability, which is another way of God's being 'in-and-beyond' in Przywara's text. The heteron is an unknowable third that is semper major just as Przywara's Creator. Perhaps Rancière's contribution is best encapsulated if we adjust the formula stipulated by the Fourth Lateran Council to read: 'between demos and polis there cannot be a likeness so great that the unlikeness is not greater'. 
Stephen Downes-Martin, 'Operations Assessments in Afghanistan is Broken. What Is to Be Done?', 64 Naval War College Review (Autumn 2011) pp. 103-126

Samuel Estreicher, 'Privileging Asymmetric Warfare (Part II)? The "Proportionality" Principle under International Humanitarian Law', Chicago Journal of International Law, pp. 143-157 (2012)

Javier Guisández Gómez, 'El Principio de la Proporcionalidad y los Daños Colaterales, un Enfoque Pragmático', in Rafael Prieto Sanjuán, Conduccion de Hostilidades y Derecho Internacional Humanitario, Bogotá (2007)

Ian Henderson, The Contemporary Law of Targeting. Military Objectives, Proportionality and Precautions in Attack under Additional Protocol I, Leiden (2009)

Jean-Marie Henckaerts and Louise Doswald-Beck, Customary International Humanitarian Law, Cambridge (2005)

Joseph Holland, 'Military Objective and Collateral Damage: Their Relationship and Dynamics', Yearbook of International Humanitarian Law, pp. 35-78 (2004)

Ernst Kantorowicz, The King's Two Bodies. A Study in Medieval Political Theology, Princeton (1957)

Pieter Hendrik Kooijmans, The Doctrine of the Legal Equality of States, Leiden (1964)

Gregor Noll, 'Sacrificial Violence and Targeting in International Humanitarian Law', in O. Engdahl and P. Wrange (eds.) Law at War: The Law as It Was and the Law as It Should Be. Liber Amicorum Ove Bring, Leiden (2008)

Anne Orford, 'Trade, Human Rights and the Economy of Sacrifice', 18 Leiden Journal of International Law, pp. 179-213, (2005)

Program on Humanitarian Policy and Conflict Research at Harvard University, Commentary on the HPCR Manual on International Law Applicable to Air and Missile Warfare, (2010)

Program on Humanitarian Policy and Conflict Research at Harvard University Manual on International Law Applicable to Air and Missile Warfare (2009)

Anne Peters, 'Humanity as the A and $\Omega$ of Sovereignty, 20 EJIL pp. 513-544 (2009)

Samuel Pufendorf, The Whole Duty of Man (2003)

Erich Przywara, Analogia Entis. Metaphysik. Ur-Struktur und All-Rhythmus, Einsiedeln (1962)

Jaques Rancière, 'The Aesthetic Dimension: Aesthetics, Politics, Knowledge', 36 Critical Inquiry, pp. $1-19$ (2009)

David Reidhav, Reasoning by Analogy - A Study on Analogy-Based Arguments in Law, Lund (2007)

Michael N. Schmitt, 'The Law of Targeting' in Elizabeth Wilmshurst and Susan Breau (eds.), Perspectives on the ICRC Study on Customary International Humanitarian Law, pp. 131-168, Cambridge (2007)

Jonathan Schroden, 'Why Operations Assessments Fail. It's Not Just the Metrics', 64 Naval War College Review, pp. 89-102. (Autumn 2011) 